\title{
Effect of three Mechanical Systems on Removal of Endotoxins from Asymptomatic Necrotic teeth with apical Periodontitis. (A randomized clinical trial)
}

\author{
Jorge Paredes Vieyra1*, Fabian Ocampo Acosta ${ }^{2}$, Daniel Cerrillo Lara ${ }^{3}$, Lizzett Lopez Yee ${ }^{4}$, Alan Hidalgo Vargas ${ }^{5}$, Mario Ignacio Manriquez \\ Quintana ${ }^{6}$
}

${ }^{1}$ Endodontics, full time professor, Autonomous University of Baja California, School of Dentistry, Tijuana campus. Calle Segunda Benito Juarez \#1014, zona Centro. Tijuana B.C. Mexico. CP 22000

${ }^{2}$ Histopathology Department, full time professor, Autonomous University of Baja California, School of Dentistry, Tijuana campus.

${ }^{3}$ Orthodontics Department, full time professor, Autonomous University of Baja California, School of Dentistry, Tijuana campus.

${ }^{4}$ Oral Surgeon, Oral Surgery department Clinical Assistant

${ }^{5}$ Universidad Autónoma de Baja California, Campus Tijuana

${ }^{6}$ Restorative dentistry, full time professor, Autonomous University of Baja California, School of Dentistry, Tijuana campus.

*Corresponding Author: Jorge Paredes Vieyra, Endodontics, full time professor, Autonomous University of Baja California, School of Dentistry, Tijuana campus. Calle Segunda Benito Juarez \#1014, zona Centro. Tijuana B.C. Mexico. CP 22000

Received date: February 26, 2021; Accepted date: March 03, 2021; Published date: March 10, 2021

Citation: Jorge P. Vieyra., Fabian O. Acosta., Daniel C. Lara., Lizzett L. Yee., Alan H. Vargas., Manriquez Quintana MI., (2021) Effect of three Mechanical Systems on Removal of Endotoxins from Asymptomatic Necrotic teeth with apical Periodontitis. (A randomized clinical trial). J. Neuroscience and Neurological Surgery. 8(2); DOI:10.31579/2578-8868/166

Copyright: ( 2021 Jorge Paredes Vieyra, This is an open-access article distributed under the terms of The Creative Commons Attribution License, which permits unrestricted use, distribution, and reproduction in any medium, provided the original author and source are credited

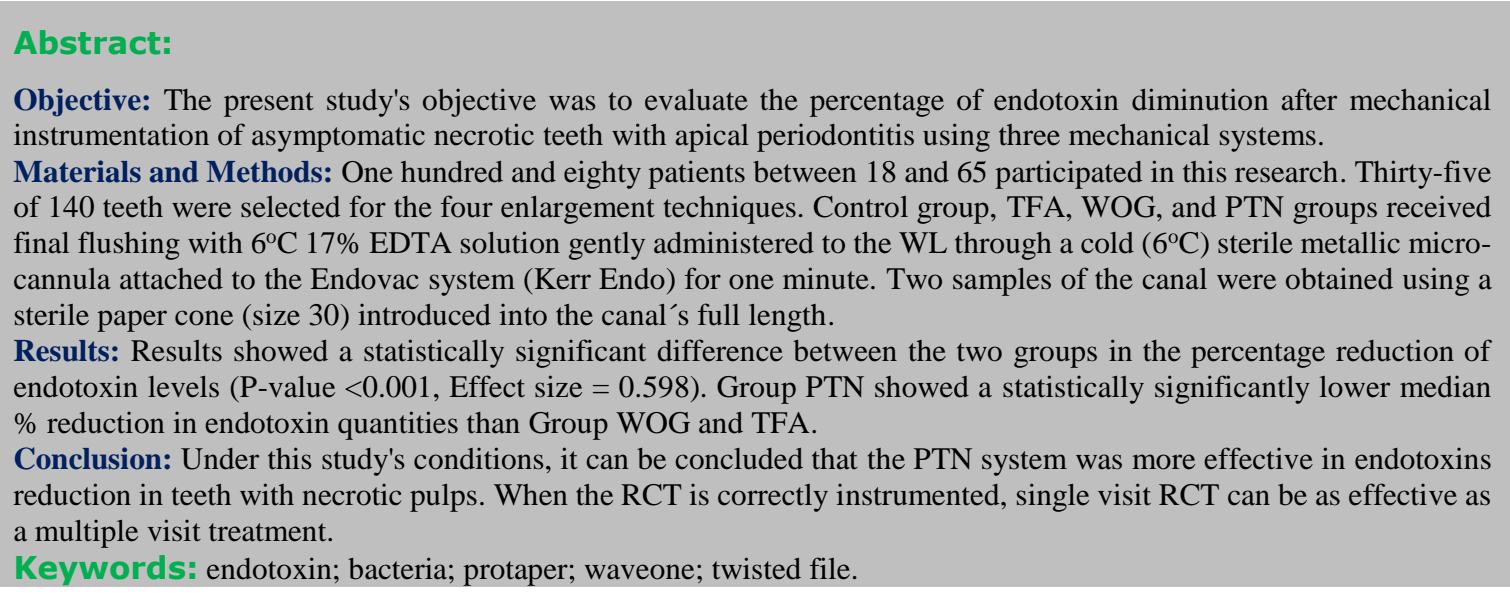

\section{Introduction}

The root canal treatment has a predictable result based on scientific evidence that guarantees high success [1]. Therefore, some cases of wellfilled canals can harbor an infection that may be the cause of the maintenance of a periapical lesion that requires retreatment by the professional [2]. The microorganisms that infect the root canal system are the main etiological factor of periapical pathologies [3].

Therefore, this type of periapical infection should be avoided, seeking the maximum elimination or reduction of microorganisms for the treatment or retreatment to be successful [4]. Reducing microbes and its by-products from the root canal $(\mathrm{RC})$ and preventing them from getting the apical zone is a crucial part of successful root canal treatment (RCT), promoting ideal periapical healing conditions [5].

During the RC preparation, debris and irrigating substances can be pushed outside the apical foramen (AF), leading to postoperative events such as demanding discomfort. Hence, the working length proper attention can decrease remains pushed through the AF [6, 7]. Gram-negative anaerobic microorganisms are the typical producers of lipopolysaccharides (LPS), called endotoxins [8]. Endotoxin is constituted of polysaccharides, lipids, and proteins, where lipid A can generate its toxic consequences. LPS is liberated during the collapse of bacteria after reproduction or death [9]. Endotoxin has been encountered in RC with pulp necrosis [10]; endotoxins stimulate competent cells to discharge, causing directly biological and immunological events, leading to an inflammatory process apical bone resorption [11]. Clinicians can find clinical endodontic symptoms such as sensitivity to percussion and palpation, exudation [12]. Numerous reports informed the instruments' mechanical action, and it is reliable for bacterial elimination $[13,14]$. The decrease of bacteria and 
biofilms is achieved by mechanical preparation and washing with mixtures of microbicides in the canal among visits $[15,16]$.

The root canals' chemical-mechanical preparation reduces the bacterial load enough to prevent them from settling and proliferating in the periapical tissues. However, there are cases in which the bacterial load is lodged in areas where the instruments cannot clean, which shows that root therapy was not enough to reduce the bacterial load and achieve success [17].

Endodontic treatment based on intracanal medication is recommended using chemical substances that manage to eliminate or inhibit the bacterial load efficiently, as demonstrated in different studies [16]. The innovation in different nickel-titanium (NiTi) systems for RCT aims to reach complicated areas of the canal, reduce preparation time, produce more focused preparations $(18,20)$, with a fewer apical projection of remains [19].

The aspects involved are the instrument's combination, type, surface treatment, rpm, and the engineering procedure. Recently, twisted adaptive files (Kavo-Kerr, USA), ProTaper Next, and WaveOne rotary system (Dentsply Maillefer, Ballaigues, Switzerland) have been manufactured M wire with significantly stable martensite stage, rising flexibility and reducing cyclical fatigue.

Additionally, the off-center quadrangular cross-section design and asymmetric rotary motion enhance channel shaping's effectiveness, as stated by the manufacturer [21].

Thus, the current randomized study's objective was to evaluate the percentage of endotoxin diminution after mechanical instrumentation of asymptomatic necrotic RC in teeth with apical periodontitis using three Ni-Ti rotary systems. A randomized trial.

The null hypothesis was that there is no significant difference in endotoxin decrease after using three Ni-Ti rotary systems.

\section{Materials and Methods}

This project was developed at the Universidad Autónoma de Baja California, Facultad de Odontología, Tijuana, México, and the trial was done following the ethical principles and agreement with the Helsinki Declaration (www.cirp.org/library/ethics/helsinki). The university institutional ethics board reviewed and approved the study under the number 2019/2-171 and was registered on www.clinical trials.gov with the number: NCT04200638.

Four qualified endodontists contributed to the project, following a preestablished technique for the Control Group (Balanced Force technique), Twisted File Adaptive (TFA), WaveOne TM (WON), and Protaper Next (PTN) instrument systems. Participants meet the criteria by medical and dental history and an appropriate intraoral and preoperative radiographic evaluation.

The inclusion parameters were: 1) pulpal necrosis verified by the response to hot and cold, and 2) radiographic evidence of apical inflammation. The clinical needs involved: a) The research needs were accepted spontaneously. b) Patients must enjoy physical and emotional well-being. c) Only necrotic pulps were incorporated. d) Negative response to the EndoIce (Hygenic Corp, Akron, $\mathrm{OH}$ ). e) Sufficient coronal structure. f) Without endodontically treated teeth. g) Any drug used in the previous seven-day study.

Exclusion parameters were teeth treated with endodontics, pregnancy, the impossibility of obtaining the patient's consent, patients under 18 years of age. Teeth with irreversible pulpitis and teeth with the apical lesion, root resorption, open apex, or a severely curved $\mathrm{RC}(>38 \mathrm{o})$ were also rejected. We also excluded patients who refused to participate in the research, those who had problems with single-visit RCTs, those who used a specific type of medication such as pain relievers or NSAIDs, and participants with rampant, systemic ailments.

Diagnostic scores were estimated by involving the tooth's reaction to a neighboring tooth with a similar vital/necrotic condition.

\section{Patient selection}

One hundred and eighty patients between 18 and 65 participated in this research (Figure 1 and Table 2). The sample size estimation was achieved, translating this particular objective into a system [22]. Hence, the forty-five teeth assigned to each group were suitable to pass a basic sample (Table 1). Randomization was completed with a randomization package (www.random.org) by a collaborator, and the random categorization chart was kept private. 


\section{CONSORT}

Ift

CONSORT 2010 Flow Diagram

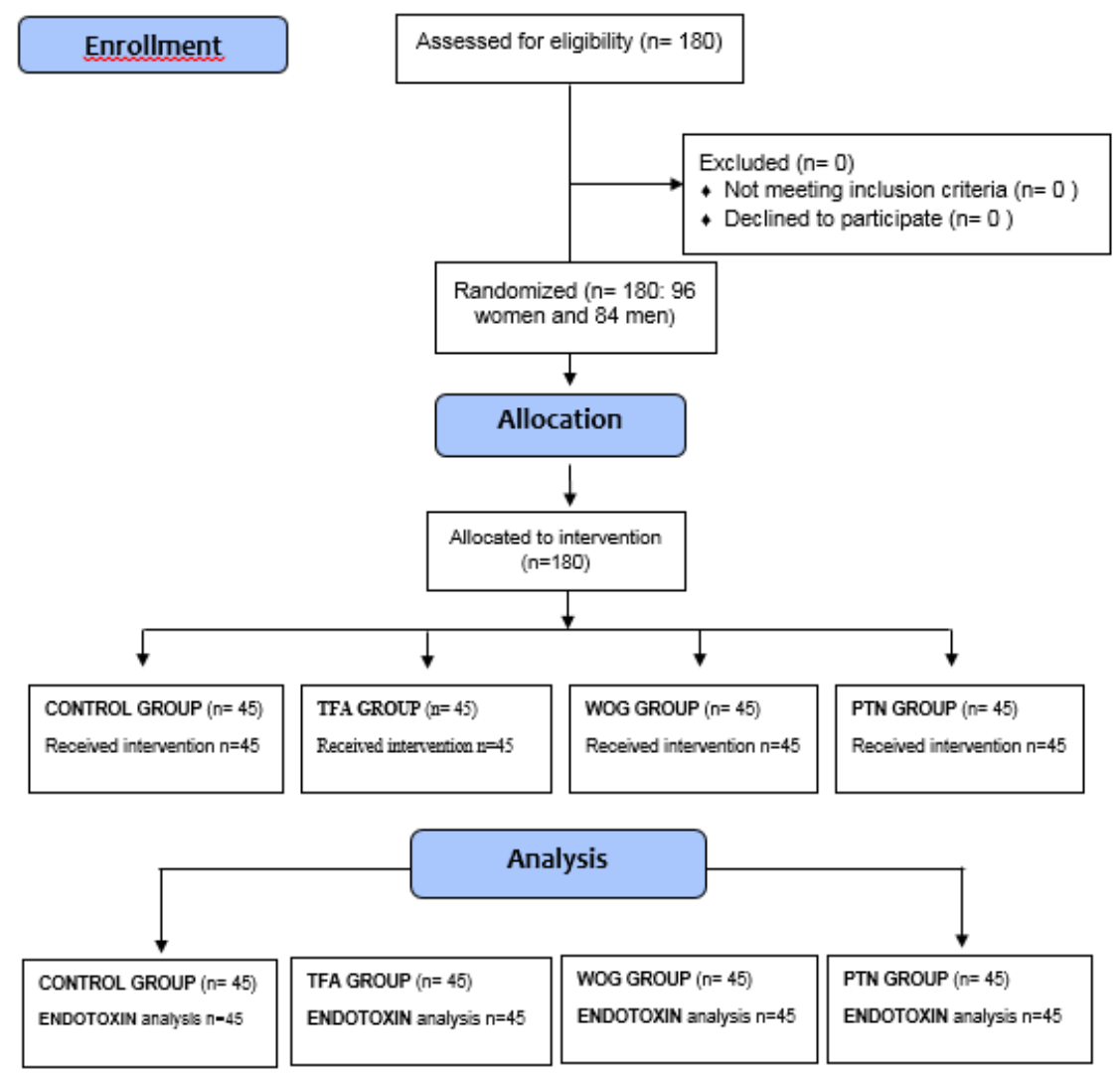

Figure 1: Consort flow diagram

The patients were randomized into four groups $(n=45)$, rendering to the kind of instruments used through the RC preparation, either Control Group (CG), Twisted File Adaptive (TFA), WaveOne TM (WON), and Protaper Next (PTN). All applicants knew the objectives, risks, and structure of the research. Printed permits and patient agreement forms for this project were obtained before enrollment. The study plan included four endodontists with more than 20 years' experience; each endodontist treated 45 teeth (Table 1, 2).

\begin{tabular}{|c|c|c|c|c|c|}
\hline & $\begin{array}{c}\text { Control } \\
\text { Group }\end{array}$ & Twisted FA & WaveOne $^{\text {TM }}$ & Protaper Next & Total \\
\hline Clinical features & $(\mathrm{CG})$ & $(\mathrm{TFA})$ & $(\mathrm{WON})$ & $(\mathrm{PTN})$ & \\
\hline & $\mathrm{n}=45$ & $\mathrm{n}=45$ & $\mathrm{n}=45$ & $\mathrm{n}=45$ & 180 \\
\hline Female & $24(53.33)$ & $24(53.33)$ & $24(53.33)$ & $24(53.33)$ & $96(53.33)$ \\
\hline Male & $21(46.66)$ & $21(46.66)$ & $21(46.66)$ & $21(46.66)$ & $84(46.66)$ \\
\hline Maxillary teeth & $31(68.88)$ & $31(68.88)$ & $31(68.88)$ & $31(68.88)$ & $124(68.88)$ \\
\hline Incisors and canines & $3(6.66)$ & $4(8.88)$ & $3(6.66)$ & $5(11.11)$ & $15(8.33)$ \\
\hline Bicuspids & $7(15.55)$ & $6(13.33$ & $7(15.55)$ & $5(11.11)$ & $25(13.88)$ \\
\hline Molars & $21(46.66)$ & $21(46.66)$ & $21(46.66)$ & $21(46.66)$ & $84(46.66)$ \\
\hline Mandibular teeth & $14(31.11)$ & $14(31.11)$ & $14(31.11)$ & $14(31.11)$ & $56(31.11)$ \\
\hline Incisor and canines & $1(2.22)$ & 0 & $1(2.22)$ & $1(2.22)$ & $3(1.66)$ \\
\hline Bicuspid & $3(6.66)$ & $4(8.88)$ & $3(6.66)$ & $2(4.44)$ & $12(6.66)$ \\
\hline
\end{tabular}

$p=0.05$

Table 1: Distribution by group of teeth 


\begin{tabular}{|l|l|c|c|}
\hline Gender & \multicolumn{1}{|c|}{ Female n (\%) } & 96 & $(53.33 \%)$ \\
\hline & Male n (\%) & 84 & $(46.66 \%)$ \\
\hline Type of teeth & Mandibular molars n (\%) & 41 & $(27.77 \%)$ \\
\hline & Mandibular premolars n (\%) & 12 & $(6.66 \%)$ \\
\hline & Mandibular anterior n (\%) & 3 & $(1.66 \%)$ \\
\hline & Maxillary molars n (\%) & 84 & $(46.66 \%)$ \\
\hline & Maxillary premolars n (\%) & 25 & $(13.885)$ \\
\hline & Maxillary anterior n (\%) & 15 & $(8.33 \%)$ \\
\hline & Asymptomatic n (\%) & 0 & \\
\hline Diagnosis & Symptomatic n (\%) & 180 & $(100 \%)$ \\
\hline & Acute pulpitis & 178 & $(98.88 \%)$ \\
\hline & Chronic pulpitis n (\%) & 2 & $(1.11 \%)$ \\
\hline
\end{tabular}

Table 2: Frequency and distribution of clinical variables

\section{Treatment Procedure}

Care was taken that all techniques were achieved under germ-free environments. Gamma Co 60 emission ( $20 \mathrm{kGy}$ for six hours) was used to sterilize and eliminate endotoxins as informed in earlier projects [18, 23]. For each treatment, a carpule of Mepivacaine Hydrochloride 2\% was handled with Levonordefrin 1: 20,000 (Septodont, Cambridge, Ontario, Canada).

The teeth were isolated and sanitized with $30 \% \mathrm{H}_{2} \mathrm{O}_{2}$ (for 25 seconds), and $2.0 \%$ sodium hypochlorite $(\mathrm{NaOCl})$ for another 25 seconds, then they were quenched with $5.0 \%$ sodium thiosulfate. The crown's access was completed using the \# 2 round bur (Dentsply International, York, PA). The access cavity was disinfected with $5.25 \% \mathrm{NaOCl}$.

The RC was explored with type K \# 10 manual files (Flex-Râ files, Union Broach, York PA, USA) depending on the foramen's initial diameter and canal's degree curvature using a watch-winding motion.

\section{Sampling method}

The first pre-operative endotoxin sample (SAM1) was obtained by introducing a \#20 sterile paper cone (Dentsply-Maillefer, Ballaigues, Switzerland) into the canal length, estimated radiographically and held in position for 1 minute, then straightway placed in sterilized glass and kept in $-20^{\circ} \mathrm{C}$. This method was repetitive, using three paper cones (Table 3).

\section{Experimental actions}

Once pre-operative endotoxin sampling (SAM1), the standard methods included the next steps: Access was obtained; SmearClear ${ }^{\mathrm{TM}}$ (Kerr Endodontics, Orange, CA) was dispensed at the entrance of the RC. WL was gaged with a \#10 k-file and the Root XZ locator (J Morita, Irvine CA, USA). A radiographic confirmation (Schick Technologies, NY, USA) was used. The cameral cavity was dry with a sanitized cotton pellet. The lubricant was positioned at the canals (i.e., lengths were made along with wet RC).

Hand enlargement. The control group $(C G)$, Balanced Force (BF) technique was used. The RC was enlarged with Flex- $\mathrm{R}^{\circledR}$ files. The canals' cervical thirds were flared with sizes \#2-\#3 Gates-Glidden burs (Dentsply Maillefer, Ballaigues, Switzerland). The RC was then rinsed with $2 \mathrm{~mL}$ $2.5 \%$ sodium hypochlorite. Complete the instrumentation phase to a size \#60 for the anterior teeth and bicuspids and to a size \#45 - \#55 in molars using SmearClear after each instrument.

Mechanical enlargement. The three techniques were used with a micro motor (Elements Motor, Sybron Endo, Glendora CA.USA). Torque and rpm were adjusted independently for each rotary file used. Twisted file adaptive $^{\mathrm{TM}}$ (TFA), WaveOne ${ }^{\mathrm{TM}}$ (WOG), and Protaper $\mathrm{Next}^{\circledR}$ (PTN) instruments were used in constant brushing and reciprocating manner, individually.

According to the manufacturer's recommendations, an alcohol pad was used to remove the smear sludge from the instruments after each use. Each canal was washed with $2.5 \mathrm{~mL} 2.5 \% \mathrm{NaOCl}$. Copious flushing of the canal was performed with a 27-G needle (Max-I-Probe; Tulsa Dental, York, PA) and a NaviTip 31-G needle (Ultradent Products Inc, South Jordan, UT) when reaching the WL once each Ni-Ti file insertion.

Group TFA. SM1 (size 20, .04 taper) and SM2 (size 25, .06 taper) instruments were used repeatedly with careful movement following manufacturer's recommendation.

Group WOG. For the WaveOne ${ }^{\mathrm{TM}}$ group, a file (25.08) was used to shape narrow, straight, curved canals, and a file (40.08) for large canals.

Group PTN. For the Pro Taper Next group, Sx files, X1, and X2 (ProTaper Universal system; Dentsply, Ballaigues, Switzerland) were used to preflare and prepare curved canals and X3 and X4 (40/.06) for the preparation of wide canals up to the WL. The instruments were operated using a constant rotary brushing motion at $300 \mathrm{rpm}$.

Hand and rotary files were used in one tooth (single use) and then eliminated.

\section{Last irrigation of the $R C$}

After instrumentations procedures, the RC space was washed with $1.5 \mathrm{~mL}$ $1.0 \% \mathrm{NaOCl}$, activated with an Irrisafe ultrasonic 20.00 tip (Satelec, Merignac, France) at $50 \%$ power of the MiniEndo ultrasonic unit (Kerr Endo) to place the tip 3-5 mm from the WL for 30 seconds per canal. Next, BF, TFA, WOG, and PTN groups received final rinsing with 1cc $6^{\circ} \mathrm{C} 17 \%$ liquid EDTA moderately managed to the WL throughout a cold $\left(6^{\circ} \mathrm{C}\right)$ disinfected metallic micro-cannula attached to the Endovac system (Discus Dental, Culver City, CA, USA) for one minute to eliminate the debris $[24,25]$. Finally, $2 \mathrm{~mL}$ of cold $\left(6^{\circ} \mathrm{C}\right)$ distilled water was used in a similar model.

The second Post-operative endotoxin sample (SAM2) was then acquired from the RC using a sterile paper cone (size 30) introduced into the canal's full length; similar actions followed in SAM1.

The RC was dried with disinfected paper cones size \#35 and filled at the same appointment. Gutta-percha cones (Dentsply Maillefer) were laterally condensed with \#20 nickel-titanium spreaders (Dentsply Maillefer) and Sealapex ${ }^{\circledR}$ sealer (SybronEndo Endodontics, Orange, CA). Obturation was considered finished when the spreader can no longer enter beyond the cervical lane. Open access of anterior teeth was etched and repaired with Fuji IX (GC Corp, Tokyo, Japan). For posterior teeth, a building up was placed with the same method. 
The RCT was done in a single visit, checked radiographically, and recorded.

\section{Primary outcome measures:}

Human Endotoxin (HET) ELISA Kit (Sandwich-ELISA method) was used to estimate the endotoxin aggrupation's in the RC previous and after chemo-mechanical procedures. The HET was extracted from the paper cone by $200 \mathrm{ul}$ of Phosphate buffered saline, then ten vortexes for 15-20 seconds followed by centrifugation for $3-5 \mathrm{~min}$ at $3000 \mathrm{xg}$. The supernatant was employed to measure the endotoxins using the Human Endotoxin ELISA Kit (12 LTD, Catalogue Number: SL0652Hu, India).

The ELISA kit uses the Sandwich-ELISA method, where the Micro-Elisa strip plate delivered in this kit has been pre-coated with an antibody precise to HET. Samples are incorporated into the suitable Micro-Elisa strip plate wells and joint to the particular antibody. Then, a Horseradish Peroxidase (HRP)-conjugated antibody exclusive for human endotoxin is added to each Micro-Elisa strip plate well and incubated. Free constituents are washed away. Only those wells that contain HET and HRP conjugated human endotoxin antibody will appear blue and then turn light yellow after the addition of the stop solution. The visual density is quantified spectrophotometrically at a wavelength of $450 \mathrm{~nm}$. The visual density value is proportional to the concentration of human endotoxins.

After the RCT, patients were requested to return for concluding restoration as fast as possible.

\section{Statistical Analysis}

Data showed non-parametric distribution, Mann- Whitney U test was used to relate between the groups, then the Wilcoxon signed-rank test was used to evaluate the variations after RC within each group (Tables 3 and 4). The significance level was set at $P \leq 0.05$. Statistical analysis was achieved with SPSS (SPSS, Inc.) Statistics Version 26 for Mac.

\section{Results}

Descriptive analysis and percentage reduction in human endotoxins were: $31.4 \%$ for CG, $79.1 \%$ for TFA, $79.4 \%$ for WOG and, $89.7 \%$ for PTN are shown in tables 3 and 4 . There was no statistically significant difference among HET levels in the created groups pre-operatively (P-value $=0.422$, Effect size $=0.142$ ). Simultaneously, there was a statistically significant difference between endotoxin levels in the four groups ( $\mathrm{P}$-value $=0.004$, Effect size $=0.480$ ) Post-operatively, where Control Group showed a statistically significantly higher median endotoxins quantity than Group PTN.

Wilcoxon signed-rank test showed a statistically significant reduction in endotoxin levels after treatment in Group WOG and TFA and in Group PTN. Results showed a statistically significant difference between the two groups in the percentage reduction of endotoxin levels (Tables 3 and 4). Group PTN showed a statistically significantly lower median \% reduction in endotoxin quantities (89.7\%) than Group WOG and TFA (79.4\% and $79.1 \%$ respectively).

\begin{tabular}{|l|c|c|c|}
\hline \multicolumn{1}{|c|}{ Instrumentation } & Time & Mean & $\begin{array}{c}\text { Standard } \\
\text { deviation }\end{array}$ \\
\hline Technique & & & \\
\hline Control Group & First Sample & 331 & 379.2 \\
\hline & Second Sample & 67.3 & 41.7 \\
\hline & Reduction & $31.4 \%$ & 10.9 \\
\hline Twisted File Adaptive & First Sample & 301 & 231.1 \\
\hline & Second Sample & 54.7 & 31.9 \\
\hline & Reduction & $79.1 \%$ & 8.7 \\
\hline Wave One & First Sample & 298 & 226.2 \\
\hline & Second Sample & 54.2 & 31.1 \\
\hline & Reduction & $79.4 \%$ & 8.3 \\
\hline Protaper Next & First Sample & 320 & 402.4 \\
\hline & Second Sample & 26.4 & 25.3 \\
\hline & Reduction & $89.7 \%$ & 5.9 \\
\hline
\end{tabular}

$\mathrm{P}$ value $=0.05$

Table 3: Descriptive statistics for endotoxin levels ( $\mathrm{pg} / \mathrm{ml})$ and percentage reduction in the four groups: Control group, Twisted file adaptive, WaveOneTM and ProTaper Next.

\begin{tabular}{|l|c|c|c|c|}
\hline & $\begin{array}{c}\text { Control Group } \\
(\text { CG) }\end{array}$ & $\begin{array}{c}\text { Twisted file adaptive } \\
\text { (TFA) }\end{array}$ & $\begin{array}{c}\text { Wave One }^{\text {TM }} \\
(\text { WON) }\end{array}$ & $\begin{array}{c}\text { Protaper Next } \\
(\text { PTN) }\end{array}$ \\
\hline & Median & Median & Median & Median \\
\hline First Sample & 207.3 & 197.7 & 196.1 & 182.7 \\
\hline Second Sample & 63.7 & 53.1 & 52.9 & 17.7 \\
\hline Reduction & $67.2 \%$ & $76.1 \%$ & $76.8 \%$ & $92.3 \%$ \\
\hline
\end{tabular}

Table 4: The median values for the four groups.

\section{Discussion}

The principal reason for RCT's failure has left bacteria and its products after RCT or the subsequent contamination of the RC due to lack of seal. When vital or necrotic teeth are treated according to clinical principles accepted under aseptic conditions, the success rate of endodontic treatment is generally high; in fact, most follow-up studies report overall success rates from $85 \%-90 \%[5,26,27]$.
Disinfecting the RC is a challenging procedure because of each canal [16], then the apical preparation was standardized to a size 30 , as various reports had described $[17,27]$. In our study, final rinsing was used with $1.5 \mathrm{~mL}$ of $6^{\circ} \mathrm{C} 17 \%$ EDTA gradually dispensed inside the RC using a cold $\left(6^{\circ} \mathrm{C}\right)$ disinfected metallic micro-cannula attached to the Endovac supported in a recent scientific report (28-29). 
The primary endodontic infection is multi-microbial, predominantly gram-negative bacterial species [30], with endotoxins present on their outer layers [31], extending into the periapical zone, leading to a chronic inflammatory process. Thus, the root canal treatment's primary objective should be eliminating of endodontic biofilm $[32,33]$. Moreover, there was a significant change in bacterial decrease when mechanical systems were related to manual procedures, as reported by some authors [33,34]. Therefore, our study aimed to estimate the percentage decrease of HET after the mechanical instrumentation of asymptomatic necrotic RC using three Ni-Ti rotary systems.

The sandwich process effectively counts a particular sample antigen, where the well surface is treated with a known quantity of bound antibody to capture the needed antigen. A specific primary antibody is then applied that "sandwiches" the antigen. Enzyme-linked secondary antibodies have added that bind to the primary antibody.

Unbound antibody-enzyme conjugates are washed off. The substrate is applied and is enzymatically converted to a color that can be later quantified. One of the benefits of using a sanitized specific antibody to capture antigen is that it excludes the necessity to purify the antigen from a mixture of other antigens, thus simplifying the assay and elevating its specificity sensitivity [35].

Our outcomes exhibited a significant decrease in the endotoxin concentration after RCT using mechanical systems. A recent study [33] described a significant bacterial load decrease after mechanical preparation. Endotoxin decreasing may be accredited to additional features, comprising the variable cross-section and more extended pitch, which are claimed to diminish the preparation time, improve cleaning efficiency, reduce the bacterial charge, and apically extruded debris [35].

Concerning the ProTaper Next group, a significant endotoxin decrease was detected after mechanical preparation, as reported in preceding studies [33,34].

This is associated with the cross-sectional design of ProTaper Next, which creates a wave of movement through rotation known as a "swaggering effect." So, it engages dentin on a larger circumference than its size. As a result, it can remove more debris than a similar-sized file with asymmetrical mass and rotation [38].

Our study informed a significant difference between inside the groups, where the percentage of HET decrease was higher with the Protaper Next system. Thus, the null hypothesis was rejected. Furthermore, the results contrast with previous findings relating to cleaning efficacy among single and multi-file systems $[14,19,20]$, which could be accredited to distinctive file systems. Therefore, it seems reasonable to assume that the mechanical action of endodontic instruments on dentine, together with copious irrigation with auxiliary solutions used, are more relevant for endotoxin removal than the number of files included in an instrumentation system.

I affirm that I/We have no financial affiliation (e.g., employment, direct payment, stock holdings, retainers, consultantships, patent-licensing arrangements or honoraria), or involvement with any commercial organization with a direct financial interest in the subject or materials discussed in this manuscript, nor have any such arrangements existed in the past three years. Any other potential conflict of interest is disclosed."

\section{Conclusion}

Under this study's conditions, it can be concluded that the Pro Taper Next rotarty system was more effective in endotoxins reduction in teeth with necrotic pulps. When the Root canal treatment is correctly instrumented, single visit RCT can be as effective as a multiple visit treatment. Finally, the use of antibacterial aids is a necessity to control endodontic infection. Clean and shape the canals is the key of success.

\section{ClinicalTrials.gov Identifier: NCT04200638}

\section{"The authors deny any conflicts of interest related to this study".}

"No potential conflict of interest was reported by the authors."

\section{References}

1. Siqueira, JF, Jr., Guimarães-Pinto, T, Rôças, IN. Effects of chemomechanical preparation with $2.5 \%$ sodium hypochlorite and intracanal medication with calcium hydroxide on cultivable bacteria in infected root canals. J Endod. 2007; 33:800-805.

2. Figdor, D, Sundqvist, G. A big role for the very small understanding the endodontic microbial flora. Aust Dent J. 2007; 52:S38-S51.

3. Ricucci D, Siqueira JF Jr. Recurrent apical periodontitis and late endodontic treatment failure related to coronal leakage: a case report. J Endod. 2011;37(8):1171-1175.

4. Siqueira, JF, Jr. Aetiology of root canal treatment failure: why well-treated teeth can fail. Int Endod J. 2001; 34:1-10.

5. Nair PN. Pathogenesis of apical periodontitis and the causes of endodontic failures. Critical Rev in Oral Biol \& Med 2004;15:348-381.

6. Ferraz CC, Gomes NV, Gomes BP, et al. Apical extrusion of debris and irrigants using two hands and three engine-driven instrumentation techniques. Int Endod J 2001;34(5): 354-358.

7. Bürklein S, Schëafer E. Apically extruded debris with reciprocating single-file and full-sequence rotary instrumentation systems. J Endod 2012; 38(6):850-852.

8. Schein B, Schilder H. Endotoxin content in endodontically involved teeth. J Endod 2006; 32:293-295.

9. Martinho FC, Chiesa WM, Marinho AC, Zaia AA, Ferraz CC, Almeida JF, Souza-Filho FJ, Gomes BP. Clinical investigation of the efficacy of chemo mechanical preparation with rotary nickel-titanium files for removal of endotoxin from primarily infected root canals. J Endod 2010;36:1766-1769.

10. Dahlen G, Bergenholtz G. Endotoxic activity in teeth with necrotic pulps. J Dent Res.1980; 59:1033-1040.

11. Pereira RS, Rodrigues VAA, Furtado WT et al. Microbial analysis of root canal and periradicular lesion associated to teeth with endodontic failure. Anaerobe 2017; 48:12-18.

12. Watkins CA, Logan HL, Kirchner HL. Anticipated and experienced pain associated with endodontic therapy. J Am Dent Assoc 2002; 133(1):45-54.

13. Shuping, GB, Ørstavik, D, Sigurdsson, A, et al. Reduction of intracanal bacteria using nickel-titanium rotary instrumentation and various medications. J Endod 2000; 26:751-755.

14. Machado ME, Nabeshima CK, Leonardo MF, Reis FA, Britto ML, Cai S. Influence of reciprocating single-file and rotary instrumentation on bacterial reduction on infected root canals. Int Endod J 2013; 46:1083-1087.

15. Paquette, L, Legner, M, Fillery, ED, et al. Antibacterial efficacy of chlorhexidine gluconate intracanal medication in vivo. $\mathrm{J}$ Endod 2007; 33:788-795.

16. Vossoghi M, Vossoghi M, Shahriari S, Faramarzi F, Mashouf RY, Farhadian M. Efficacy of a novel rotary system in reduction of intracanal bacteria: An in Vitro Study. Iran Endod J 2016;11:219.

17. Peters OA. Current challenges and concepts in the preparation of root canal systems: a review. J Endod 2004;30:559-567. 
18. Martinho FC, Gomes AP, Fernandes AM, Ferreira NS, Endo MS, Freitas LF, Camões IC. Clinical comparison of the effectiveness of single-file reciprocating systems and rotary systems for removal of endotoxins and cultivable bacteria from primarily infected root canals. J Endod 2014;40:625-629.

19. De-Deus G, Brandão MC, Barino B, Di Giorgi K, Fidel RA, Luna AS. Assessment of apically extruded debris produced by the single-file ProTaper F2 technique under reciprocating movement. Oral Surg Oral Med Oral Pathol Oral Radiol Endod 2010; 110:390-394.

20. Neves MA, Provenzano JC, Rôças IN, Siqueira Jr JF. Clinical antibacterial effectiveness of root canal preparation with reciprocating single-instrument or continuously rotating multiinstrument systems. J Endod 2016;42:25-29.

21. Elnaghy AM. Response: Cyclic fatigue resistance of ProTaper Next nickel-titanium rotary instruments. Int Endod J 2015; 48:1101.

22. Woolson RF, Bean JA, Rojas PB. Biometrics. 1986; 42: $927-$ 932.

23. Xavier AC, Martinho FC, Chung A, Oliveira LD, Jorge AO, Valera MC, Carvalho CA. One-visit versus two-visit root canal treatment: effectiveness in the removal of endotoxins and cultivable bacteria. J Endod 2013;39:959-964.

24. Kirchhoff AL, Fariniuk LF, Mello I. Apical extrusion of debris in flat-oval root canals after using different instrumentation systems. J Endod 2015; 41(2):237-241.

25. Nielsen \& Baumgartner Comparison of the EndoVac system to needle irrigation of root canal. J Endod 2007;33:(5):611-625.

26. Nixdorf DR, Moana-Filho EJ, Law AS, et al. Frequency of persistent tooth pain after root canal therapy: a systematic review and meta-analysis. J Endod 2010; 36:224-230.

27. Dagna A, Arciola CR, Visai L, Selan L, Colombo M, Bianchi S, Poggio C. Antibacterial efficacy of conventional and singleuse Ni-Ti endodontic instruments: an in vitro microbiological evaluation. Int J Artif Organs.2012;35:826-831.

28. Bleakley CM, McDonough SM, MacAuley DC, et al. Cryotherapy for acute ankle sprains: a randomized controlled study of two different icing protocols. Br J Sports Med 2006; 40(8):700-705.
29. Al-Nahlawi T, Abo Hatab T, Abd Alrazak M, et al. Effect of intracanal cryotherapy and negative irrigation technique on post endodontic pain. J Contemp Dent Pract 2016; 17(2):990996.

30. Esk M, Sadrhaghighi H, Rahmani M, Majd NM, Sadighi A. Comparison of two mechanical instrumentation techniques in reducing root canal bacterial population. Afr $\mathrm{J}$ Microbiol Res.2012; 6:3635-3638.

31. Siqueira JF, Lima KC, Magalhães FA, Lopes HP, de Uzeda M. Mechanical reduction of the bacterial population in the root canal by three instrumentation techniques. J Endod 1999; 25: 332-335.

32. Nabeshima CK, Caballero-Flores H, Cai S, Aranguren J, Britto ML, de Lima Machado ME. Bacterial removal promoted by 2 single-file systems: Wave One and One Shape. J Endod 2014; 40:1995-1998.

33. Karataş E, Gültekin E, Arslan H, Kırıcı DÖ, Alsancak M, Topçu MÇ. Evaluation of instrumentation systems in reducing E. faecalis from root canals: TF adaptive and ProTaper next versus single file systems. Int J Artif Organs 2015;38:161-164.

34. Tewari RK, Ali S, Mishra SK, Kumar A, Andrabi SM, Zoya A, Alam S. Mechanical reduction of the intracanal Enterococcus faecalis population by Hyflex CM, K3 XF, ProTaper Next, and two manuals instrument systems: an in vitro comparative study. $\mathrm{J}$ invest and clin dent 2016; 7:168-173.

35. Liu R, Hou BX, Wesselink PR, Wu MK, Shemesh H. The incidence of root microcracks caused by 3 different single-file systems versus the ProTaper system. J Endod.2013;39:10541056.

36. Gan SD, Patel KR. Enzyme immunoassay and enzyme-linked immunosorbent assay. J Invest Dermatol.2013;133:e12.

37. Dhingra A, Kochar R, Banerjee S, Srivastava P. Comparative evaluation of the canal curvature modifications after instrumentation with One Shape rotary and Wave One reciprocating files. J conser dent 2014;17:138.

38. Ruddle CJ [cited on 25 Nov 2013]. Available from: http://dentistrytoday. com/endodontics/8865-the-shaping movement-fifth generation-technology.
This work is licensed under Creative Commons Attribution 4.0 License
To Submit Your Article Click Here: Submit Manuscript

DOI:10.31579/2578-8868/166
Ready to submit your research? Choose Auctores and benefit from:

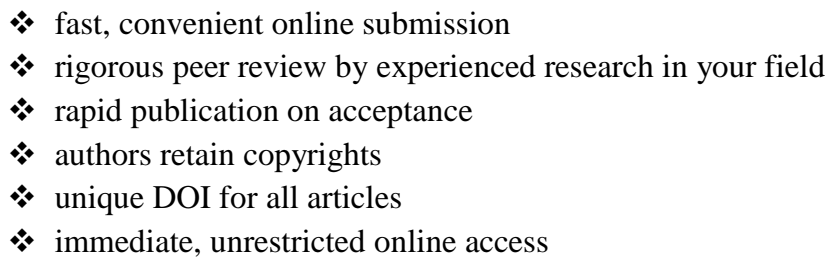

At Auctores, research is always in progress.

Learn more www.auctoresonline.org/journals/neuroscience-andneurological-surgery 